УДК 349.2

DOI https: / / doi.org/10.32837 / yuv.v0i3.1929

\title{
О. Карпушова,
}

суддя Шостого апеляціиного адміністративного суду

\section{ПРИТЯГНЕННЯ СУДДІВ ДО ДИСЦИПЛІНАРНОЇ ВІДПОВІДАЛЬНОСТІ В УКРАЇНІ}

Постановка проблеми. Українські вчені цілком справедливо наголошують на тому, що у трудових відносинах за участю суддів «роботодавцем виступає держава в особі уповноваженого органу, а для судді, як працівника, характерний специфічний дуальний статус працівника та державного службовця» [1, с. 299]. Суддя так само, як і будь-який інший працівник, який уклав трудовий договір, набуває певних прав і обов'язків (хоча сам характер i зміст трудової функції суддів має певні особливості), а також несе відповідальність за реалізацію своїх прав і виконання обов'язків. У цьому сенсі йдеться про юридичну відповідальність у трудовому праві, що є суттєвою проблемою для доктрини трудового права [2-5]. Додатково актуалізує це питання той факт, що юридична відповідальність судді, як працівника, є більш суворою порівняно з працівниками загалом.

Вказане зумовлене тим, що судді [6, с. 13-35] є особливими суб'єктами трудового права (віднесені до спеціальної категорії працівників, тобто працівників зі спеціальним правовим статусом). Саме судді, як представники судової системи, є «суб'єктами, наділеними відповідними правами та обов'язками, які дозволяють їм повністю виконувати свої трудові функції для забезпечення законності в суспільстві та верховенства права» [7, с. 195]. При цьому вказані обов'язки повинні виконуватися суддями сумлінно, беручи до уваги той факт, що «сумлінність у виконанні трудових обов'язків судді диктується статусом і рівнем відповідальності за прийняті рішення» [8, с. 689].

Український вчений В.В. Кузьменко зауважує, що «реалізація принципу верховенства права у суспільстві $€$ допустимою лише за умови визнання законів та тих інституцій, які їх приймають і забезпечують реалізацію, причому функціонування всього державного механізму є можливим виключно за умови належного виконання такими установами своїх функцій. Особливість трудової функції суддів полягає в необхідності дотримання як законодавчо встановлених норм, так і вимог морального змісту. Ix недодержання чи аморальна поведінка під час роботи або у побуті є підставою для притягнення таких працівників до відповідальності» $[9$, с. 11].

О.Л. Польовий зазначає, що «відсутність відповідальності судді за свідоме та систематичне порушення закону породжує його безвідповідальність, підриває авторитет судової влади та віру громадян у справедливість держави» [10, с. 65]. Вказане зумовлює те, що український законодавець передбачає підвищену дисциплінарну відповідальність для суддів, а українські вчені приділяють ретельну увагу цьому феномену.

Питання дисциплінованості суддів $€$ досить актуальним, зважаючи на динаміку зростання кількості фактів притягнення суддів до дисциплінарної відповідальності. Згідно інформації, розміщеної на офіційному веб-сайті Вищої ради правосуддя (у спеціальному розділі веб-сайту 
«Інформація про притягнення суддів до дисциплінарної відповідальності»), у 2017 році до дисциплінарної відповідальності було притягнуто 96 суддів, у 2018 році - 176 суддів, у 2019 році (станом на вересень 2019 року) 123 суддів.

Аналіз наукової літератури та не вирішені раніше питання. Загальні аспекти трудо-правового режиму дисциплінарної відповідальності загалом та режиму дисциплінарної відповідальності суддів в Україні зокрема привертають широку увагу українських науковців. Ці питання вже розглядали у своїх дослідженнях Т.В. Андрейчук, В.М. Андріїв, В.П. Бойко, В.В. Волинець, В.В. Гладкий, М.В. Данилова, М.А. Дідиченко, О.Ю. Дрозд, В.І. Журавель, Я.С. Зливко, І.Б. Іваночко, М.І. Іншин, І.Г. Козуб, А.Ю. Коротких, М.М. Кухта, П.С. Луцюк, О.П. Машевська, Л.М. Москвич, Г.М. Мурашин, Л.П. Нестерчук, О.М. Овчаренко, Є.Ю. Пономаренко, С.В. Прилуцький, В.О. Процевський, Л.В. Прудиус, А.С. Шевченко, О.М. Ярошенко та інші вітчизняні науковці.

Не применшуючи важливості наукового внеску цих та інших вчених у вирішення вказаного питання, слід констатувати, що у світлі поточної судово-правової реформи питання притягнення суддів до дисциплінарної відповідальності потребує комплексного осмислення, на підставі чого можна буде сформулювати узагальнюючі висновки про перспективи розвитку правового регулювання відповідної кадрової процедури.

Метою цієї розвідки $є$ узагальнення наукової думки про особливості притягнення суддів до дисциплінарної відповідальності в Україні. Ця мета досягатиметься виконанням таких завдань: 1) встановити сутність дисциплінарної відповідальності суддів в Україні; 2) з'ясувати нормативну базу, на основі якої здійснюється притягнення суддів до дисциплінарної відповідальності; 3) окреслити сутність правового режиму дисциплінар- ної відповідальності суддів в Україні, беручи до уваги норми національного законодавства про судоустрій і статус суддів; 4) узагальнити результати дослідження.

Виклад основного матеріалу дослідження. «Дисциплінарна відповідальність», як справедливо зауважує український науковець П.С. Луцюк, є «юридичною відповідальністю у трудовому праві дисциплінарного характеру» [11, с. 256] (в контексті консолідуючого підходу до розуміння юридичної відповідальності в трудовому праві [12, с. 41]) та «таким видом юридичної відповідальності, що застосовується в рамках трудового права на підставі норм чинного законодавства до працівника, який умисно чи 3 необережності вчинив дисциплінарний проступок, та характеризується зумовленням спеціального правового статусу порушника (його обов'язком зазнати негативних наслідків морального, організаційного та матеріального характеру) та суб'єкта дисциплінарної влади (правом накласти на порушника трудової дисципліни дисциплінарне стягнення на підставі та у порядку, передбаченому чинним законодавством)»[13, с. 196-197]

Дисциплінарною відповідальністю державних службовців загалом, на думку українського правника та судді А.Ю. Коротких, є «окремий специфічний вираз юридичної відповідальності в трудовому праві», який: 1) «реалізується відповідно до правил і стандартів, встановлених у законодавстві про працю, а також в окремих спеціальних нормативно-правових актах (які не обов'язково $є$ частиною трудового законодавства, зокрема в нормативно-правових актах адміністративного законодавства)»; 2) «виявляється в практичній дійсності у застосуванні до винуватого (у порушенні службової дисципліни) державного службовця негативних заходів впливу особистого чи майнового характеру» [14, с. 200-201]. 
У світлі викладеного слід погодитися з тим, що дисциплінарна відповідальність суддів є застосуванням до суддів спеціально уповноваженими органами «юридичних санкцій за правопорушення в службовій і неслужбовій сфері, визначених Конституцією України і законодавством про судоустрій у вигляді дисциплінарних стягнень у встановленому законом порядку, та перетерпівання суддями відповідних обмежень організаційного та особистого характеру» [15, с. 7].

Метою такої відповідальності суддів (як комплексного міжгалузевого правового інституту та спеціального виду дисциплінарної відповідальності) $€$ «забезпечення виконання ними своїх службових обов'язків, дотримання дисципліни і стабільності функціонування судової системи України та гарантування права зацікавлених осіб на справедливий суд» [16, с. 202].

Нині дисциплінарна відповідальність врегульовується розділом VI Закону України «Про судоустрій і статус суддів», яким визначаються підстави цієї відповідальності згідно ст. 106 Закону:

1) допущення суддею поведінки, яка порочить звання судді або підриває авторитет правосуддя, зокрема в питаннях моралі, чесності, непідкупності, відповідності способу життя судді його статусу, дотримання інших норм суддівської етики та стандартів поведінки, які забезпечують суспільну довіру до суду, вияв неповаги до інших суддів, адвокатів, експертів, свідків чи інших учасників судового процесу; ненадання інформації або надання завідомо недостовірної інформації на законну вимогу члена Вищої кваліфікаційної комісії суддів України (далі BKKCУ) та/або члена Вищої ради правосуддя (далі - ВРП), у тому числі недодержання встановлених законом строків надання інформації тощо. При цьому законодавець зазначає, що скасування або зміна судового рішення не має наслідком дисциплінарної відповідальності судді, який брав участь в його ухваленні, крім випадків, коли скасоване або змінене рішення ухвалено внаслідок умисного порушення норм права чи неналежного ставлення до службових обов'язків.

У практичній дійсності одні й ті ж діi судді можуть вважатися як правомірною поведінкою, так і дисциплінарним проступком. На одну з таких дискусійних ситуацій звертає увагу B.B. Гладкий, критично аналізуючи етичну допустимість користування суддями у судових засіданнях сучасними технічними засобами, «а саме смартфонами, планшетами, ноутбуками тощо». Український вчений звертає увагу на те, що, окрім користування технічними засобами в розважальних цілях (що під час судового засідання може тлумачитися в якості дисциплінарного проступку), суддя може використовувати відповідні засоби в етичних межах.

«Судді, намагаючись справедливо, всебічно вирішити конкретний спір i постановити справедливе рішення, можуть і повинні використовувати для цього всі допустимі засоби, не відмовляючись при цьому і від результатів науково-технічного прогресу людства, не боячись виконувати покладені на них народом України функції. Тобто, судді можуть використовувати смартфони, планшети, ноутбуки, наприклад, для перевірки чинності нормативно-правових актів у часі, перевірки інших загальновідомих фактів об'єктивної дійсності тощо.

Науковець цілком справедливо звертає увагу на те, що «умови катастрофічного навантаження на суддів (особливо в адміністративних судах), яке динамічно зростає, деструктивно вПливаючи на життєздатність судової влади, зумовлює ситуації, коли судді практично весь свій час проводять на робочому місці, не зустрічаючись зі своїми близькими родичами». У цьому контексті «цілком закономірно, що в таких умовах судді з тих чи інших об'єктивних причин іноді (тобто, це не звичайні, а екстраординарні випадки) змушені, уникаючи 
затягування процесу розгляду справи, вирішувати особисті справи, не ставлячи під сумнів цінність життя, гідність і почуття учасників судового процесу, не допускаючи своїми діями обмеження їх процесуальних прав, не шкодячи ідеї правосуддя».

В якості проміжного висновку вчений наголошує, що «етичність відповідних дій суддів взагалі і в кожному конкретному випадку зокрема» $€$ «в окресленому контексті питанням не правовим, а філософським» [17, с. 182-184];

2) особливості звернення 3 дисциплінарною скаргою щодо судді ст. 107 Закону. Право на звернення з такою скаргою має будь-яка особа. При цьому громадяни здійснюють зазначене право особисто чи через адвоката, юридичні особи - через адвоката, органи державної влади та органи місцевого самоврядування через своїх керівників або представників, Комісія з питань доброчесності та етики - через іiі голову або членів комісіі;

3) орган, який здійснює дисциплінарне провадження щодо судді, - ст. 108 Закону. Таким органом є ВРП, що здійснює відповідне провадження у порядку, закріпленому у Главі 4 та інших положеннях Закону України «Про Вищу раду правосуддя»;

4) перелік дисциплінарних стягнень стосовно судді та особливості їх застосування - ст. 109 Закону: попередження; догана - 3 позбавленням права на отримання доплат до посадового окладу судді протягом одного місяця; сувора догана - 3 позбавленням права на отримання доплат до посадового окладу судді протягом трьох місяців; подання про тимчасове (від одного до шести місяців) відсторонення від здійснення правосуддя з позбавленням права на отримання доплат до посадового окладу судді та обов'язковим направленням судді до Національної школи суддів України для проходження курсу підвищення кваліфікації, визначеного органом, який здійснює дисциплінарне провадження щодо суддів, та подальшим кваліфікаційним оцінюванням для підтвердження здатності судді здійснювати правосуддя у відповідному суді; подання про переведення судді до суду нижчого рівня; подання про звільнення судді з посади;

5) особливості погашення дисциплінарного стягнення - ст. 110 Закону. Хоча у цьому питанні до суддів застосовується загальна логіка припинення стану «покараності» (тобто, логіка, викладена у законодавстві про працю), слід констатувати й певні особливості цієї кадрової процедури, що врегульована у законодавстві про судоустрій і статус суддів, адже диференціюється залежно від виду дисциплінарного стягнення, які застосовуються до суддів.

Так, у загальному випадку погашення дисциплінарного стягнення має місце після спливу 6 місяців дисциплінованого виконання трудових обов'язків; у разі накладення дисциплінарного стягнення у виді догани - після спливу 12 місяців дисциплінованого виконання трудових обов'язків; у разі накладення дисциплінарного стягнення у виді суворої догани - після спливу 18 місяців дисциплінованого виконання трудових обов'язків; у разі накладення дисциплінарного стягнення у виді подання про тимчасове відсторонення судді після спливу 24 місяців дисциплінованого виконання трудових обов'язків, а також за умови успішного проходження курсу підвищення кваліфікації, подальшого підтвердження здатності здійснювати правосуддя у відповідному суді за результатами кваліфікаційного оцінювання; у разі накладення дисциплінарного стягнення у виді подання про переведення судді до суду нижчого рівня - після спливу 36 місяців дисциплінованого виконання трудових обов'язків;

6) оскарження рішення у дисциплінарній справі стосовно судді -

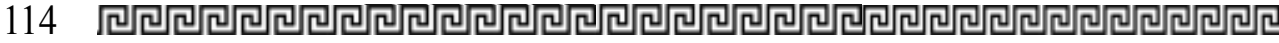


ст. 111 Закону. Суддя може оскаржити рішення про притягнення його до дисциплінарної відповідальності 3 підстав та у межах спеціального порядку, що врегульовується положеннями Закону України «Про Вищу раду правосуддя».

Висновки. Викладене дає підстави стверджувати, що натепер в Україні вдало сформовано правовий режим притягнення суддів до дисциплінарної відповідальності. Попри це відповідний правовий режим не позбавлений низки недоліків, які шкодять праву працівника не бути безпідставно притягнутим до юридичної відповідальності. Це питання актуалізується тим, що нині має місце певна дискусійність нормативних i фактичних підстав притягнення суддів до дисциплінарної відповідальності. Зокрема, відсутність належної юридичної визначеності у питанні складу дисциплінарного проступку суддів призводить до того, що це питання стає предметом надто широкого тлумачення нормативної та ненормативної поведінки суддів, що може шкодити стану незалежності трудової діяльності судді.

У процесі поточної судово-правової реформи законодавцю доцільно уточнити нормативну підставу, на основі якої суддя притягується до дисциплінарної відповідальності, а також окреслити нормативні застереження щодо: 1) меж тлумачення дисциплінованої та недисциплінованої поведінки суддів в Україні; 2) рівня ненормативності, констатація якого дозволяє дійти думки про факт дисциплінарного проступку. Це питання, на нашу думку, може бути належним чином вирішене шляхом аналізу низки рішень Ради суддів України та Вищої ради правосуддя, в яких присвячено значну увагу розмежуванню нормативності й ненормативності поведінки судді, а також належному рівню ненормативності поведінки судді, що $є$ достатньою для притягнення такого працівника до дисциплінарної відповідальності.
Стаття присвячена узагальненню актуальної наукової думки про особливості притягнення суддів до дисииплінарної відповідальності в Україні. Автором встановлюеться сутність дисциплінарної відповідальності суддів в Україні та з'ясовуються особливості правового регулювання кадрової процедури притягнення суддів до дисцииллінарної відповідальності. Особлива увага приділяеться дискусійності нормативних і фактичних підстав притягнення суддів до дисииплінарної відповідальності.

Наголошується на тому, що відсутність належної юридичної визначеності у питанні складу дисииплінарного проступку суддів призводить до того, щзо ије питання стае предметом надто иирокого тлумачення нормативної та ненормативної поведінки суддів, що може шкодити стану незалежності трудової діяльності судді.

3'ясовано, шо скасування або зміна судового рішення не мають наслідком дисциилінарну відповідальність судді, який брав участь в його ухваленні, крім випадків, коли скасоване або змінене рішення ухвалено внаслідок умисного порушення норм права чи неналежного ставлення до службових обов'язків.

Зроблено висновок, що нині в Україні вдало сформовано правовий режим притягнення суддів до дисииплінарної відповідальності. Попри це відповідний правовий режим не позбавлений низки недоліків, які шкодять праву працівника не бути безпідставно притягнутим до юридичної відповідальності. Це питання актуалізується тим, що натепер має місце певна дискусійність нормативних $i$ фактичних підстав притягнення суддів до дисииилінарної відповідальності. Зокрема, відсутність належної юридичної визначеності у питанні складу дисцииплінарного проступку суддів призводить до того, що ие 
питання стає предметом надто широкого тлумачення нормативної та ненормативної поведінки суддів, що може шкодити стану незалежності трудової діяльності судді.

Саме тому у процесі поточної судово-правової реформи законодавию доцільно уточнити нормативну підставу, на основі якої суддя притягується до дисииплінарної відповідальності, а також окреслити нормативні застереження щзодо: 1) меж тлумачення дисциплінованої та недисциилінованої поведінки суддів в Україні; 2) рівня ненормативності, констатація якого дозволяе дійти думки про факт дисициллінарного проступку.

Ключові слова: дисциплінарний проступок, дисциплінована поведінка, етична поведінка, робота судді, службова дисципліна, суддя.

Karpushova 0 . Bringing of judges to the disciplinary liability in Ukraine

The article is devoted to the generalization of current scientific ideas about the specifics of bringing judges to disciplinary responsibility in Ukraine. The author establishes the essence of the disciplinary responsibility of judges in Ukraine and elucidates the features of the legal regulation of the personnel procedure for bringing judges to disciplinary responsibility.

Special attention is paid to the discussion of normative and factual grounds for bringing judges to disciplinary responsibility. It is emphasized that the lack of proper legal certainty in the issue of the composition of disciplinary misconduct of judges leads to the fact that this issue becomes the subject of too broad interpretation of normative and non-normative behavior of judges, which can harm the state of independence of the judge's work.

It has been established that the revocation or amendment of a court decision does not result in disciplinary liability of the judge who participated in its adoption, except in cases where the revoked or amended decision was adopted as a result of intentional violation of law or improper treatment of official duties. It is concluded that the legal regime of bringing judges to disciplinary responsibility has been successfully formed in Ukraine. Nevertheless, the relevant legal regime is not without many shortcomings that harm the employee's right not to be unjustifiably prosecuted.

This issue is actualized by the fact that at present there is a certain debatability of normative and factual grounds for bringing judges to disciplinary responsibility. In particular, the lack of proper legal certainty in the composition of judges' disciplinary misconduct leads to the fact that this issue becomes the subject of too broad an interpretation of normative and non-normative behavior of judges, which may harm the state of independence of judges.

That is why, in the process of current judicial reform, the legislator should clarify the regulatory basis on which a judge is subject to disciplinary action, as well as outline regulatory provisions on: 1) the limits of interpretation of disciplined and undisciplined behavior of judges in Ukraine; 2) the level of nonnormativeness, the statement of which allows to reach opinions about the fact of disciplinary misconduct.

Key words: disciplinary offense, disciplined behavior, ethical conduct, judge, official discipline, work of a judge.

\section{Лiтература}

1. Яворська Н.О. Правова природа трудових відносин суддів. Актуальні проблеми права: теорія і практика. 2016. № 32. C. 293-300.

2. Зубрицький M.I. Теоретико-методологічні та прикладні засади правового регулювання відносин у сфері юридичної відповідальності державних службовців в 
Україні : дис. д-ра юрид. наук: 12.00.05. Київ, 2019. 421 c.

3. Іншин М.I. Узагальнена характеристика сутності, особливостей, проблем юридичної відповідальності державних службовців за трудовим законодавством України. Соціальне право. 2018. № 1. С. 62-71.

4. Коротких А.Ю. Юридична відповідальність державних службовиів за трудовим законодавством України: теорія, практика, проблеми : монографія. Харків : Константа, 2019. 420 c.

5. Луц̧юк П.С. Сучасна парадигма юридичної відповідальності у трудовому праві України : монографія Харків : У справі, 2017. 502 с.

6. Карпушова О.В. Правовий механізм забезпечення $i$ реалізачіі трудових прав суддів : дис. канд. юрид. наук: 12.00.05. Дніпропетровськ, 2016. $211 \mathrm{c}$.

7. Курбанов Б.Б. Сутність і значення захисту суб'єктивних трудових прав суддів. Форум права. 2014. № 4. С. 195-198.

8. Штих T.В. Права $і$ обов'язки суддi як суб'єкта трудового права. Форум права. 2009. № 3. С. 686-690.

9. Кузьменко В.В. Юридична відповідальність суддів за порушення законодавства про пращю: дис. канд. юрид. наук: 12.00.05. Сєвєродонеиьк, 2017. 192 c.

10. Польовий О.Л. Гарантії суддівської незалежності при притягненні суддів до юридичної відповідальності : дис. канд. юрид. наук: 12.00.10. Київ, 2014. 227 c.
11. Луцьюк П.С. Концепція юридичної відповідальності в трудовому праві України. Актуальні проблеми права: теорія і практика. 2016. № 32. С. 252-258.

12. Волинець B.B. Основні підходи до розуміння юридичної відповідальності в сучасному трудовому праві. Науковий вісник публічного та приватного права. 2017. Bun. 6, T. 3. C. 37-42.

13. Луйюк П.С. Концептуальні засади юридичної відповідальності в сучасних умовах розвитку трудового законодавства : дис. д-ра юрид. наук: 12.00.05. Сєверодонецьк, 2017. 468 с.

14. Коротких А.Ю. Проблеми юридичної відповідальності державних службовців за трудовим законодавством України : дис. д-ра юрид. наук: 12.00.05. Київ, 2019. 472 c.

15. Виноградова Л.Є. Юридична відповідальність суддів загальних судів Україні: 12.00.10. Одеса, 2004. 16 c.

16. Шевченко А.В. Дисциплінарна відповідальність суддів України: дис. канд. юрид. наук: 12.00.10. Київ, 2013. 260 c.

17. Гладкий В.В. Субъективная сторона вопроса использования судьями технических средств во время судебного заседания. Правові засоби забезпечення та захисту прав людини: вітчизняний та зарубіжний досвід : матер. Міжнар. наук.-практ. конф. (м. Сєвєродонещьк, 13-14 квітня 2017 року). Сєвєродонецьк: СНУ ім. В. Даля, 2017. С. 181-185. 